\title{
Coronavírus e COVID-19
}

\author{
Coronavirus and COVID-19 \\ Coronavirus y COVID-19
}

RECEBIDO EM: 26/03/2020 APROVADO EM: 02/04/2020

\section{Maria Lucia Costa de Moura}

Enfermeira. Doutora em Patologia Ambiental. Universidade Paulista - UNIP. Orcid: https://orcid.org/0000-0002-0700-9564

C oronavírus é uma família de vírus que causam infecções respiratórias. Recebe esse nome porque as características (a imagem) do vírus se assemelham a uma coroa (corona, em espanhol). Esse agente infeccioso foi pela primeira vez identificado em humanos e isolado em 1937. Porém, só foi descrito como Coronavírus em 1965, quando a análise de perfil na microscopia revelou essa aparência ${ }^{(1)}$.

Para acompanhar o novo vírus descoberto em 31 de dezembro de 2019, e que tem atraído a atenção das autoridades de saúde em todo mundo, foi nomeado tecnicamente de COVID-19. Por também ter aparência de coroa, ele tem sido chamado de novo Coronavírus. Os primeiros casos desse agente foram registrados em Wuhan, na China ${ }^{(1)}$.

Diante disso, embora as autoridades de saúde estejam em alerta, a maioria das pessoas se infecta com os Coronavírus comuns ao longo da vida, sendo as crianças pequenas mais propensas a se infectarem com essas variantes. Os tipos mais regulares que infectam humanos são o alpha Coronavírus 229E e NL63 e o beta Coronavírus OC43, HKU1 ${ }^{(1)}$.

Vale lembrar que os Coronavírus são vírus de RNA de fita positiva envolvidos, que se replicam no citoplasma. Para entregar seu nucleocapsídeo na célula hospedeira, eles dependem da fusão de seu envelope com a membrana da célula hospedeira. A glicoproteína spike $(S)$ media a entrada do vírus e é um determinante primário do tropismo e patogênese celular ${ }^{(2)}$.

Sendo assim, é classificada como uma proteína de fusão classe I e é responsável pela ligação ao receptor na célula hospedeira, além de mediar a fusão do hospedeiro e das membranas virais - processo que é impulsionado pelas principais alterações conformacionais da proteína $S^{(2)}$.

Nesse contexto, os Coronavírus ganharam notoriedade particular quando o surto grave da síndrome respiratória aguda (SARS) abalou o mundo em 2002-2003. $\mathrm{O}$ interesse por essa família de vírus cresceu após a epidemia, levando a identificação de muitos novos membros da família. Este episódio também lançou luz sobre a capacidade de Coronavírus para saltar barreiras através das espécies. Antes de ganhar importância para a saúde pública em 2003, as doenças associadas ao Coronavírus eram principalmente de interesse veterinário ${ }^{(3)}$.

Dando continuidade, os Coronavírus infectam uma ampla variedade de mamíferos e aves, causando doenças respiratórias e entéricas e, em alguns casos mais raros, hepatite e doença neurológica. A infecção pode ser aguda ou persistente. Os Coronavírus são classificados em quatro gêneros diferentes, historicamente baseados em análises sorológicas e agora em estudos genéticos: alfa, beta, gama e delta- $\mathrm{CoV}^{(4)}$ e, além dessa classificação, os Coronavírus pertencem à Subfamília Coronaviridae que, juntamente com Torovirinae, forma a família Coronaviridae na Ordem Nido$\operatorname{viral}^{(2)}$.

Tendo em vista essa afirmação, a entrada viral depende de uma boa interação entre $o$ virion e a célula hospedeira. A infecção é iniciada pela interação da partícula viral com proteínas específicas na superfície celular. Os Coronavírus usam uma variedade de receptores e gatilhos para ativar a fusão, no entanto, aspectos fundamentais que permitem essa etapa inicial do ciclo de vida viral são conservados ${ }^{(2)}$.

Portanto, como mencionado acima, o emparelhamento de proteína/receptor de pico de Coronavírus é um determinante chave do tropismo. Para infectar uma nova espécie hospedeira, os Coronavírus devem se adaptar ao receptor de seu novo hospedeiro por mutação ou por recombinação com um Coronavírus infectando seu novo hospedeiro. No caso do SARS-CoV, o vírus apareceu em 2002 nos mercados de varejo de animais vivos na China ${ }^{(5)}$.

Para continuar, alguns autores ${ }^{(5)}$ afirmam que vírus relacionados foram isolados de civetas (Paradoxurushermaphroditus) das palmeiras do Himalaia, também chamados de musang ou civeta de palmeira asiática, cães-guaxinim e furões chineses; no entanto, acredita-se que esses animais não eram o reservatório do vírus, mas hospedeiros intermediários durante o evento de salto da espécie. O receptor da SARS-CoV é a enzima conversora de angiotensina 2 (peptídeo do sistema renina-angiotensina-aldosterona - SRAA). Esse peptídeo tem um papel importante na regulação da pressão arterial (ACE2).

\section{O CORONAVIRUS ENTRANDO EM UMA CÉLULA VULNERÁVEL}

Autores $^{(6)}$ explicam a entrada do vírus 
na célula, e como é do conhecimento de todos, o vírus entra no corpo através do nariz, boca ou olhos e depois se liga às células das vias aéreas que produzem uma proteína chamada ACE2. Acredita-se que o vírus tenha se originado em morcegos, onde pode ter se ligado a uma proteína semelhante.

Não obstante, na célula há liberação do RNA, material genético, após fundir a sua membrana com a da célula humana. A célula infectada lê o RNA e começa a produzir proteínas que manterão o sistema imunológico sob controle ajudando a criar novas cópias do vírus, e à medida que a infecção progride, o mecanismo da célula começa a produzir novos picos e outras proteínas que formarão mais cópias do Coronavírus, disseminando a infecçãoo ${ }^{(6)}$.

Continuando, cada célula infectada pode liberar milhões de cópias do vírus antes que a célula finalmente se quebre e morra. Os vírus podem infectar células próximas ou acabar em gotículas que escapam dos pulmões.

\section{RESPOSTA IMUNE}

A maioria das infecções por Covid-19 causam febre, porque o sistema imunológico luta para eliminar o vírus. Em casos graves, essa reação imunológica pode atacar as células pulmonares. Os pulmões ficam obstruídos com fluido e células moribundas, dificultando a respiração. Uma pequena porcentagem de infecções pode levar à síndrome do desconforto respiratório agudo e, possivelmente, à morte ${ }^{(6)}$.

Tendo em vista essa afirmação, o diretor do Centro Médico de Doenças Infecciosas, Owen Tsang Tak-Yin, os pacientes curados da doença se cansam muito facilmente e, alguns deles, podem ter uma queda de 20 a 30\% na função pulmonar ${ }^{(7)}$.

Antibióticos matam bactérias e não funcionam contra vírus. Mas os pesquisadores estão testando medicamentos antivirais que podem interromper as proteínas virais e parar a infecção.
A doença de

Coronavírus

(COVID-19) é uma

doença infecciosa

causada por um

Coronavírus

recém-descoberto.

A maioria das

pessoas infectadas

com o vírus

COVID-19

experimentará

doença respiratória

leve a moderada

e se recuperará

sem a necessidade

de tratamento

especial.
COVID-19

A doença de Coronavírus (COVID-19) é uma doença infecciosa causada por um Coronavírus recém-descoberto. A maioria das pessoas infectadas com o vírus COVID-19 experimentará doença respiratória leve a moderada e se recuperará sem a necessidade de tratamento especial. Os idosos e aqueles com problemas médicos subjacentes, como doenças cardiovasculares, diabetes, doenças respiratórias crônicas e câncer, têm maior probabilidade de desenvolver doenças graves ${ }^{(8)}$.

Pensando dessa forma, a melhor maneira de prevenir e desacelerar a transmissão é estar bem informado sobre o vírus COVID-19, a doença que causa e como se espalha. Proteja-se e a outros de infecções lavando as mãos ou usando um esfregão à base de álcool nos pisos com frequência, e evite tocar sempre no rosto ${ }^{(8)}$.

Vale enfatizar que o vírus da $\mathrm{CO}$ VID-19 se dissemina, principalmente, por gotículas de saliva ou secreção nasal quando uma pessoa infectada tosse ou espirra; portanto, é importante que se pratique etiqueta respiratória - por exemplo, tossindo em um cotovelo flexionado ${ }^{(8)}$.

Nesse contexto, já que no momento não existem vacinas ou tratamentos específicos para a COVID-19, é necessário um maior cuidado com tudo e com todos. No entanto, existem muitos ensaios clínicos em andamento avaliando possíveis tratamentos. A Organização Mundial de Saúde (OMS) continuará fornecendo informações atualizadas assim que os achados clínicos estiverem disponíveis ${ }^{(8)}$.

Em todos os outros contextos, as evidências disponíveis indicam que o vírus da COVID-19 é transmitido durante contato próximo através de gotículas respiratórias, como tosse, ou espirros e por fômites (objetos contaminados). O vírus pode se espalhar diretamente de pessoa para pessoa quando uma pessoa infectada tosse ou exala produzindo gotículas que atingem o nariz, boca ou olhos de outra pessoa ${ }^{(9)}$. 
Outro destaque significativo é sobre as gotículas que são muito pesadas para serem transportadas pelo ar, por isso elas pousam em objetos e superfícies ao redor de uma pessoa, bastando tocar nos objetos ou superfícies, levando as mãos ao nariz, boca ou aos olhos, outras pessoas serão infectadas. Importante a distância de uma pessoa para outra de um metro ou mais, limitando essa propagaçãa ${ }^{(9)}$.

Vale apontar que os profissionais de saúde, por ficarem muito próximos do doente devido ao atendimento clínico, a geração de aerossóis incide diretamente nesse profissional. Como tal, a OMS continua recomendando que todos realizem a higienização das mãos com frequência, seguindo as recomendações de etiqueta e regularmente limpe e desinfete as superfícies. Atentando para a importância de manter distâncias físicas e evitar pessoas com febre ou sintomas respiratórios ${ }^{(9)}$.

Sendo assim, estas medidas preventivas limitarão a transmissão viral. Desde o início do surto da COVID-19 e em alinhamento com as evidências disponíveis, a OMS mantém a recomendação a respeito de precauções contra gotículas e contato para o uso de máscaras médicas (N95, FFP2 ou FFP3) para cuidados regulares de pacientes e os cuidados com os respiradores COVID-19, principalmente, devido a circunstâncias e configurações nas quais a geração de aerossóis pode acontecer durante os procedimentos com o paciente ${ }^{(9)}$.

\section{DEFINIÇÕES DE CASO}

De acordo com a OMS, onde atualiza periodicamente a Vigilância Global para a infecção humana por Coronavírus COVID-19(9).

\section{Caso suspeito}

A. Um paciente com doença respiratória aguda (febre e pelo menos um sinal/ sintoma de doença respiratória, como tosse e falta de ar), e sem outra etiologia que explique completamente a apresentação clínica: um histórico de viagens ou residência em um país/área ou território que comunica transmissão local nos últimos dias;

B. Um paciente com qualquer doença respiratória aguda, e houve contato com um caso confirmado ou provável de $\mathrm{CO}$ VID-19, nos últimos 14 dias antes do início dos sintomas;

C. Paciente com infecção respiratória aguda grave (febre e pelo menos um sinal/ sintoma de doença respiratória, como tosse e falta de ar) que exija hospitalização, e sem outra etiologia que explique completamente a apresentação clínica.

\section{Caso provável}

Um caso suspeito para quem o teste para COVID-19 é inconclusivo, relatado pelo laboratório;

\section{Caso confirmado}

Pessoa com confirmação laboratorial da infecção por COVID-19, independentemente de sinais e sintomas clínicos.

\section{REFERÊNCIAS}

1. Ministério da Saúde (BR). Entenda a diferença entre Coronavírus, Covid-19 e Novo Coronavírus [Internet]. Brasília: Ministério da Saúde, 2020 [acesso em 04 abr 2020]. Disponível em: https://www.gov.br/pt-br/noticias/saude-e-vigilancia-sanitaria/2020/03/entenda-a-diferenca-entre-coronavirus-covid-19-e-novo-coronavirus.

2. Belouzard S, Millet JK, Licitra BN, Whittaker GR. Mechanisms of Coronavírus Cell Entry Mediated by the Viral Spike. Viruses [Internet]. 2012 [acesso em 04 abr 2020]; 4:1011-1033. Disponivel em: https://www.ncbi.nlm.nih.gov/pmc/articles/ PMC3397359/pdf/viruses-04-01011.pdf.

3. Navas-Martin S, Weiss SR. Coronavírus pathogenesis and the emerging pathogen severe acute respiratory syndrome coronavírus. Rev Microbiol Mol Biol [Internet]. 2005 dez [acesso em 04 abr 2020]; 69(4):635-64. Disponivel em: https://www.ncbi.nlm. nih.gov/pubmed/16339739.

4. Beaudette FR, Hudson CB. Infection of the cloaca with the virus of infectious bronchitis. Science [Internet]. 1932 [acesso em 04 abr 2020]; 76(1958):34. Disponivel em: https://www. ncbi.nlm.nih.gov/pubmed/17732084.

5. Wenhui Li, Moore MJ, Vasilieva N, Sui J, Wong SK, Berna MA, et al. Angiotensin-converting enzyme 2 is a functional receptor for the SARS coronavírus. Natureza [Internet]. 2003 [acesso em 04 abr 2020]; 426(6965):450-4. Disponivel em: https://www. ncbi.nlm.nih.gov/pubmed/14647384.

6. Corum J, Zimmer C. How Coronavírus Hijacks Your Cells. In: Dr. Matthew B. Frieman and Dr. Stuart Weston, Univ. of Maryland School of Medicine; Fields Virology; Fenner and White's Medical Virology; Nature; Science; The Lancet; New England Journal of Medicine; Centers for Disease Control and Prevention. The New York Times Company [Internet]. 2020 Mar [acesso em 04 abr 2020]. Disponível em:

https://www.nytimes.com/interactive/2020/03/11/science/ how-coronavirus-hijacks-your-cells.html.

7. Cury ME. Mesmo curados, pacientes de Covid-19 podem ter problemas pulmonares. Rev. Exame [Internet]. 2020 [acesso em 04 abr 2020]. Disponivel em: https://exame.abril.com.br/ ciencia/mesmo-curados-pacientes-de-covid-19-podem-ter-problemas-pulmonares/.

8. World Health Organization. Coronavirus [Internet]. 2020 [acesso em 04 abr 2020]. Disponivel em: https://www.who.int/ health-topics/coronavirus\#tab=tab_1.

9 World Health Organization. Coronavirus Disease (COVID-19) TECHNICAL GUIDANCE: infection prevention and control/wash [Internet]. 2019 [acesso em 04 abr 2020]. Disponivel em: https://www.who.int/emergencies/diseases/ novel-coronavirus-2019/technical-guidance/infection-prevention-and-control 